\title{
DIGITAL MODEL TO PREDICT EFFECTS OF PUMPING FROM THE ARIKAREE AQUIFER IN THE DWYER AREA, SOUTHEASTERN WYOMING
}

U. S. GEOLOGICAL SURVEY

Water-Resources Investigations/Open-File Report 8-76 [76-8]

Prepared in cooperation with the Wyoming Department of Economic Planning and Development

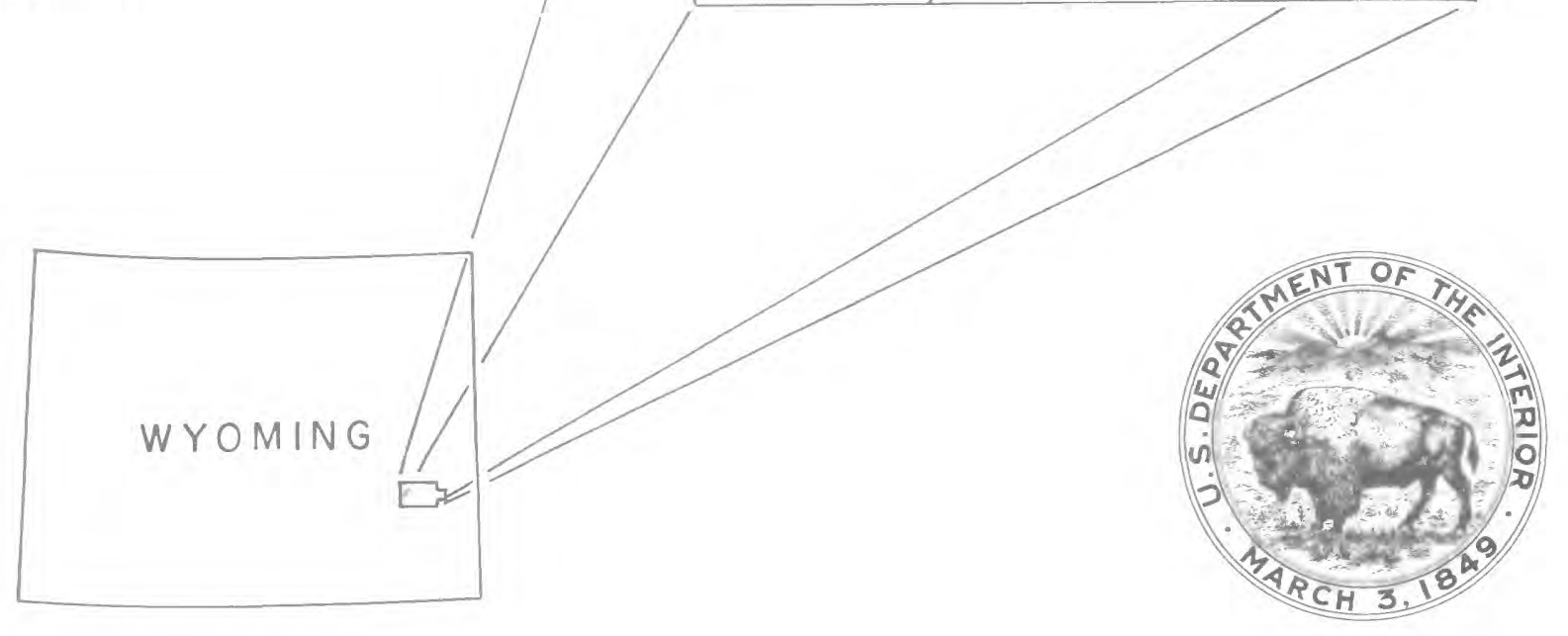


Digital model to predict effects of pumping from the Arikaree aquifer in the Dwyer area, southeastern Wyoming.

\section{Report Date}

February 1976

6.

8. Performing Organization Rept. No. USGS/WRI $-8-76$

10. Project/Task/Work Unit No.

11. Contract/Grant No.

13. Type of Report \& Period Covered

Final

14.

Cheyenne, Wyoming 82001

15. Supplementary Notes

Prepared in cooperation with the Jyoming Department of Economic Planning and Development.

16. Abstracts A digital computer model was used to model an unconfined sandstone aquifer (Arikaree aquifer) in about 340 square miles ( 880 square kilometres) in southeastern Wyoming. The model was calibrated by comparing observed and calculated changes in the potentiometric surface and leakage from the aquifer along streams during water year 1974. The comparison was fairly good for changes in the potentiometric surface and was good for leakage. The calibrated model was used to predict changes in the potentiometric surface and leakage through water year 1979, assuming no new ground-water development after 1974 and normal recharge to the aquifer. Water-level declines of as much as 14 feet ( 4.3 metres) were predicted, but much of the area would be relatively unaffected. The total predicted decrease in leakage between water years 1974 and 1979 was about 500 acre-feet (0.6 cubic hectometre) per year; the greatest decrease was predicted along streams closest to areas of pumpage.

17. Key Words and Document Analysis. 17a. Descriptors

*Surface-ground water relationships, *Computer models, *Aquifer characteristics, *Wyoming, Ground water, Transmissivity, Specific yield, Recharge, Discharge, Potentiometric level, Observation wells, Effluent streams.

7b. Identifiers/Open-Ended Terms

Southeastern Wyoming

Arikaree aquifer

7c. COSATI Field Group

8. Availability Statement

19. Security Class (This Report)

No restriction on distribution.
UNCLASSIFIED

20. Security Class (This Page

UNCLASSIFIED
21. No. of Pages

22. Price 
DIGITAL MODEL TO PREDICT EFFECTS OF PUMPING FROM THE ARIKAREE AQUIFER IN THE DWYER AREA, SOUTHEASTERN WYOMING By Gregory C. Lines

U.S. GEOLOGICAL SURVEY

Water-Resources Investigations/Open-File Report 8-76 [76-8]

Prepared in cooperation with the

Wyoming Department of Economic Planning and Development

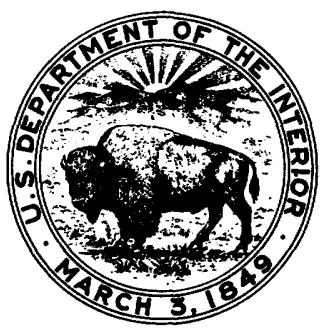




\section{UNITED STATES DEPARTMENT OF THE INTERIOR}

Thomas S. Kleppe, Secretary

GEOLOGICAL SURVEY

V. E. McKelvey, Director

\section{OPEN-FILE REPORT}

For additional information write to:

U.S. Geological Survey

4015 Warren Avenue, P.0. Box 2087

Cheyenne, Wyoming 82001 
Abstract-_-

Introduction-

Purpose of investigation- 1

Previous investigations- 4

Methods of investigation-- 4

Wel1-numbering system-_-_- 5

Acknowledgments-_-_-_-_- 5

The Arikaree aquifer-_- 6

Potentiometric surface-1- 6

Saturated thickness--_- 6

Hydraulic conductivity-_- 7

Specific yield-_-_-_- 7

Recharge from precipitation- 8

Leakage along streams-_-_- 8

Cottonwood Creek-_-_- 10

North Platte River-_-_-_-_- 10

North Laramie River-_-_-_-_-_-_-_-_-_-_-_- 11

Laramie River above North Laramie River-_-_-_-_-_-_- 11

Laramie River below North Laramie River-_-_-_--- 12

Evapotranspiration-_-_-_-_- 12

Underflow--_-_-_- 13

Recharge from North Laramie Canal-_- 13

Pumpage--_- 14

The digital model- 14

Model calibration--_-_-_-_- 15

Model predictions-_- 20

Summary and conclusions-_-_ 22

Selected references-_- 24

\section{ILLUSTRATIONS}

Figure 1. Map of Wyoming showing the area described in this report--_-_-_- 2

2. Number of irrigation wells and the quantity of water pumped in the Dwyer area, water years 1969-74-----

3. Data-collection network showing location of observation wells, irrigation wells, test holes, and surface-water measuring sites in the Dwyer area, southeastern Wyoming-- In pocket

4. Geologic map and configuration of the base of the Arikaree aquifer in the Dwyer area, southeastern Wyoming-- In pocket 
Figure 5. Potentiometric surface of the Arikaree aquifer in the Dwyer area, southeastern Wyoming,

September 1973In pocket

6. Saturated thickness of the Arikaree aquifer in the Dwyer area, southeastern Wyoming, September 1973--- In pocket

7. Simplified flow chart showing major steps of the digital model-

8. Finite-difference grid and boundary conditions used to model Arikaree aquifer in the Dwyer area, southeastern Wyoming- In pocket

9. Observed and calculated potentiometric surface at two wells during calibration period-- 18

10. Calculated leakage from the Arikaree aquifer to flood-plain deposits along streams in the Dwyer area during water year 1974-C-

11. Monthly recharge to and discharge from the Arikaree aquifer in the modeled area during water year 1974

12. Transmissivity of the Arikaree aquifer in the Dwyer area, southeastern Wyoming, generated from saturated thickness and adjusted hydraulic conductivity, September 1973- In pocket

13. Predicted change in the potentiometric surface of the Arikaree aquifer in the Dwyer area, southeastern Wyoming, water years 1974-79, assuming no new development after water year 1974 In pocket

14. Predicted leakage from the Arikaree aquifer along streams in the Dwyer area during water years 1974-79 assuming no new development after water year 1974

TABLE

Table 1. Discharge measurements made at various sites along Page streams and the North Laramie Canal 
DIGITAL MODEL TO PREDICT EFFECTS OF PUMPING FROM THE ARIKAREE AQUIFER

IN THE DWYER AREA, SOUTHEASTERN WYOMING

By Gregory C. Lines

\begin{abstract}
A digital computer model was developed and used to simulate an unconfined sandstone aquifer (Arikaree aquifer) in about 340 square miles (880 square kilometres) in southeastern Wyoming. The model was calibrated by comparing observed and calculated changes in the potentiometric surface and leakage from the aquifer along streams during water year 1974. The comparison was fairly good for changes in the potentiometric surface and was good for leakage. The calibrated model was used to predict changes in the potentiometric surface and leakage through water year 1979, assuming no new ground-water development after 1974 and 6.5 percent of the normal precipitation as recharge to the aquifer. Water-level declines of as much as 14 feet ( 4.3 metres) were predicted, but much of the area would be relatively unaffected. The total predicted decrease in leakage between water years 1974 and 1979 was about 500 acre-feet ( 0.6 cubic hectometre) per year; the greatest decrease was predicted along streams closest to areas of pumpage.
\end{abstract}

\title{
INTRODUCTION
}

This investigation was made by the U.S. Geological Survey between July 1973 and June 1975 in cooperation with the Wyoming Department of Economic Planning and Development. The study area described in this report is in the northern high plains of southeastern Wyoming and includes about 340 square miles $\left(880 \mathrm{~km}^{2}\right)$ in Platte and Goshen Counties (fig. 1). The small community of Dwyer is in the approximate center of the area. The area of study is bounded on the north by the ground-water divide north of Cottonwood Creek, on the northeast by the North Platte River, on the south by the Laramie and Dry Laramie Rivers, on the southeast by the Wheatland fault system, and on the west by outcrop of rocks of preTertiary age.

Twenty-two irrigation we1ls were drilled in the Dwyer area between 1969 and 1974 (fig. 2). All the wells tap an unconfined sandstone aquifer, referred to in this report as the Arikaree aquifer, at depths usually less than 600 feet $(200 \mathrm{~m})$. Three of the wells also tap a confined aquifer in the lower part of the White River Formation and three other wells also tap flood-plain deposits. Because large-yield wells--those yielding more than $500 \mathrm{gal} / \mathrm{min}$ (32 1/s)--have been completed and all the surface water in the area is appropriated, there is an increasing interest in ground water for irrigation. Industry is also interested in the ground-water potential of the area because of the proximity of the area to coal deposits in northeastern Wyoming. 


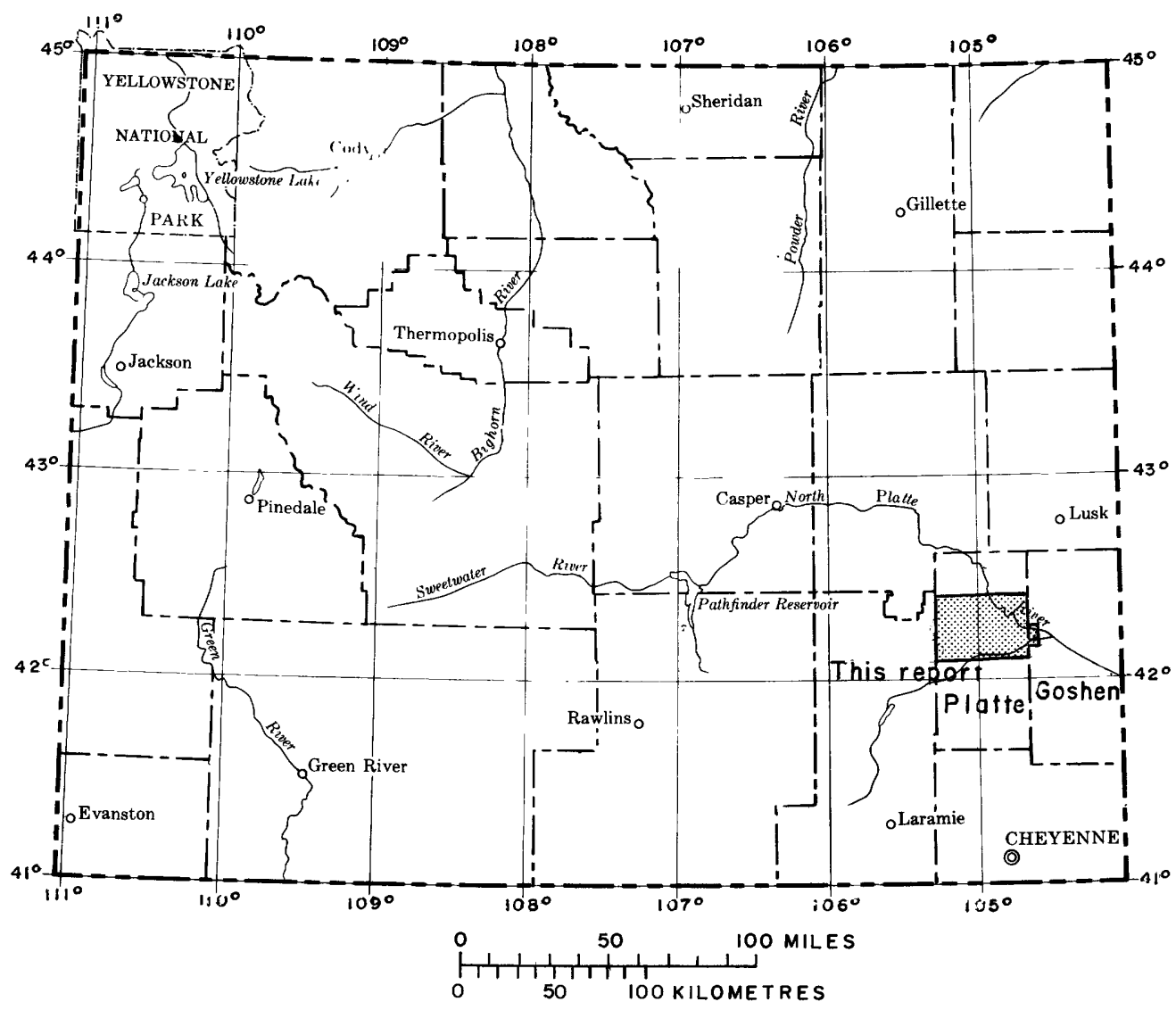

Figure 1.-Map of Wyoming showing the area described in this report. 


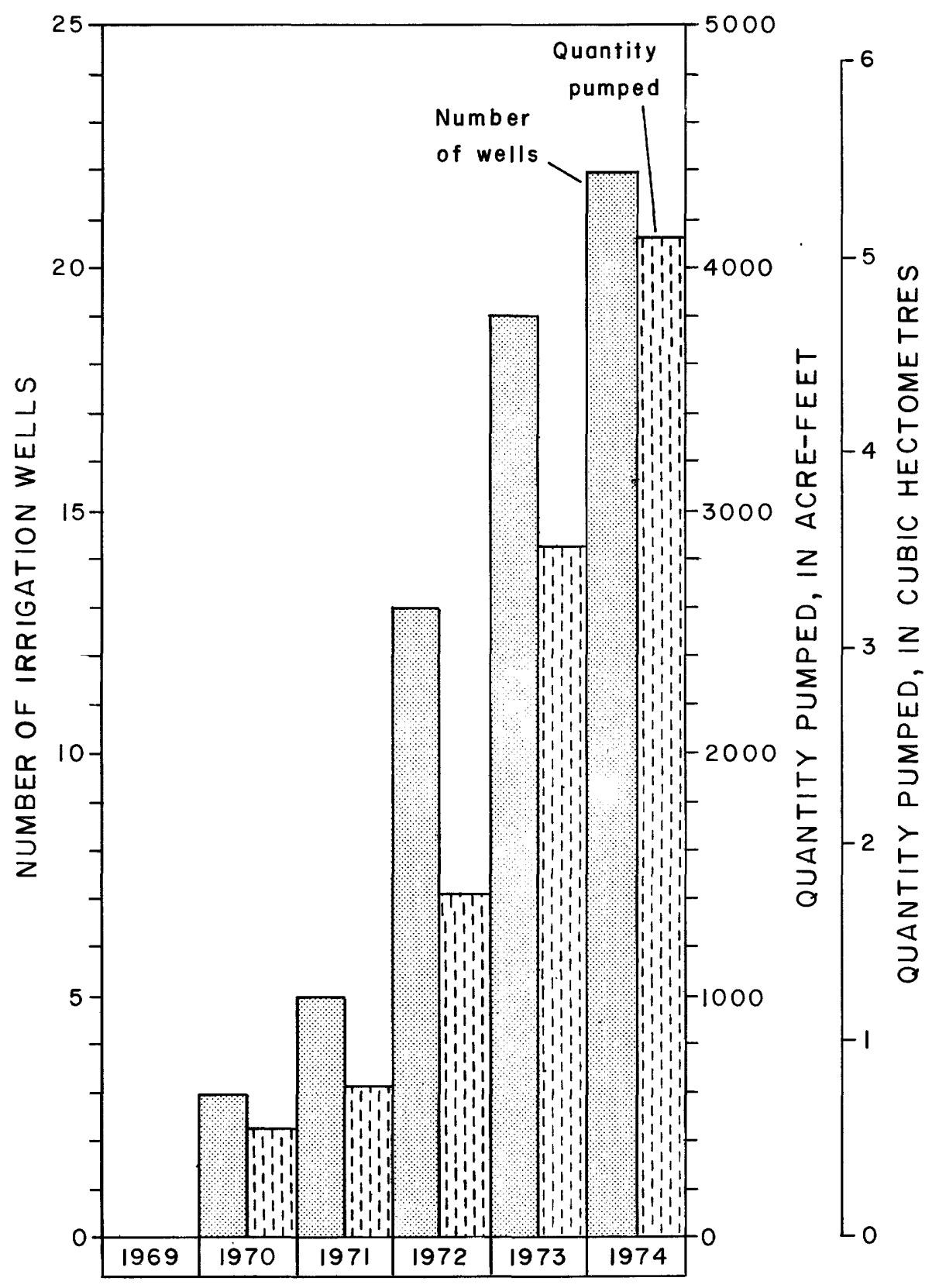

Figure 2.- Number of irrigation wells and the quantity of water pumped in the Dwyer area, water years 1969-74. 
State water administrators need to know the effects of ground-water withdrawals on ground-water levels and on streamflow. To date, only a meager amount of quantitative information, often not specifically related to the Dwyer area, has been available to guide water-supply developers and managers.

For those readers who may prefer to use metric units, the conversion factors for English units used in this report are listed below. The conversion factors are shown to four significant figures; however, in the report, the metric equivalents are shown only to the number of significant figures consistent with the values for the English units.

\begin{tabular}{|c|c|c|}
\hline ultiply English unit & By & To obtain metric unit \\
\hline $\begin{array}{l}\text { feet (ft) } \\
\text { cubic feet }\left(\mathrm{ft}^{3}\right) \\
\text { miles (mi) } \\
\text { feet per mile (ft/mi) } \\
\text { acres } \\
\text { square miles }\left(\mathrm{mi}^{2}\right) \\
\text { acre-feet (acre-ft) } \\
\text { feet per day (ft/day) } \\
\text { cubic feet per second }\left(\mathrm{ft}^{3} / \mathrm{s}\right) \\
\text { feet squared per day }\left(\mathrm{ft}^{2} / \mathrm{day}\right) \\
\text { cubic feet per second } \mathrm{per}^{2} \\
\left.\quad \text { square mile [(ft } 3 / \mathrm{s}) / \mathrm{mi}^{2}\right] \\
\text { gallons per minute (gal/min) }\end{array}$ & $\begin{array}{c}0.3048 \\
.02832 \\
1.609 \\
.1894 \\
.004047 \\
2.590 \\
.001233 \\
.3048 \\
.02832 \\
.09290 \\
.01093\end{array}$ & $\begin{array}{l}\text { metres }(\mathrm{m}) \\
\text { cubic metres }\left(\mathrm{m}^{3}\right) \\
\text { kilometres }(\mathrm{km}) \\
\text { metres per kilometre }(\mathrm{m} / \mathrm{km}) \\
\text { square kilometres }\left(\mathrm{km}^{2}\right) \\
\text { square kilometres }\left(\mathrm{km}^{2}\right) \\
\text { cubic hectometres }\left(\mathrm{hm}^{3}\right) \\
\text { metres per day }(\mathrm{m} / \mathrm{day}) \\
\text { cubic metres per second }\left(\mathrm{m}^{3} / \mathrm{s}\right) \\
\text { metres squared per day }\left(\mathrm{m}^{2} / \mathrm{day}\right) \\
\text { cubic metres per second per } \\
\text { square kilometre }\left[\left(\mathrm{m}^{3} / \mathrm{s}\right) / \mathrm{km}^{2}\right] \\
\text { litres per second }(1 / \mathrm{s})\end{array}$ \\
\hline
\end{tabular}

\section{Purpose of Investigation}

The objective of this study was to develop a digital model of the Arikaree aquifer that would simulate the effects of ground-water withdrawals on water levels in the aquifer and discharge from the aquifer along streams.

\section{Previous Investigations}

Previous investigations in and adjacent to the Dwyer area include: 1) A ground-water reconnaissance of the Glendo-Wendover area by Rapp and Babcock (1953), 2) a study of the ground-water resources of Goshen County by Rapp and others (1957), 3) a study of the geology and groundwater resources of Platte County by Morris and Babcock (1960), and 4) a study of hydrologic conditions in Wheatland Flats by Weeks (1964).

\section{Methods of Investigation}

The study was designed so that the model would be calibrated for water year 1974 (October 1973 through September 1974) on a monthly basis, that is, water-level changes and aquifer leakage to the streams were calculated at the end of each month. 
A11 irrigation we1ls (fig. 3) in the area that tap the Arikaree aquifer were inventoried. Electric-power consumption and efficiencytest data were used to estimate pumpage at each we11. Interpretations of electric logs, drillers' logs, surface outcrops, and existing pumping tests were used to define the water-bearing properties and extent of the Arikaree aquifer. Water levels in about 150 wells were measured in September 1973 to define the potentiometric surface at the beginning of the calibration period. Discharge measurements at gaging stations and other sites along streams were used to define natural discharge from and recharge to the aquifer, as well as to calibrate the model. Recharge to the Arikaree aquifer along the North Laramie Canal was also estimated from discharge measurements. Monthly water-level measurements during water year 1974 at 34 observation wells were used to estimate changes in ground-water storage, to estimate the specific yield of the aquifer, and to calibrate the mode1. The results of the data-collection phase of the study, the model calibration, and model predictions are described in more detail in following sections of the report.

\section{We11-Numbering System}

The we11 numbers used in this report indicate the location of the we11s by township, range, section, and position within the section. The first number of a well number indicates the township, the second the range, and the third the section in which the well is located. The lowercase letters following the section number indicate the position of the well within the section. The first letter denotes the quarter section, the second the quarter-quarter section, and the third the quarter-quarter-quarter section [10 acre $\left(0.040 \mathrm{~km}^{2}\right)$ tract]. The subdivisions of the sections are lettered $a, b, c$, and $d$ in a counterclockwise direction, beginning in the northeast quarter. For example, wel1 25-66-18bcc is 1ocated in the SW $\frac{1}{4} \mathrm{SW}^{\frac{1}{4}} \mathrm{NW} \frac{1}{4}$ of section 18, Township 25 North, Range 66 West.

This numbering system was used also to designate locations where discharge measurements were made along streams.

\section{Acknowledgments}

Appreciation is extended to the many landowners in the Dwyer area who supplied information on their wells and allowed access to their property for various measurements. Without their cooperation, this study would not have been possible.

Norman M. Denson, of the U.S. Geological Survey, supplied a geologic map of Tertiary rocks in the Dwyer area and was very helpful in the interpretation of electric logs. 
The geology of the Dwyer area is shown in figure 4 along with descriptions of geologic units. Rocks of pre-Tertiary age crop out along the western and northeastern boundaries of the area, but in most of the area they are covered with a thick mantle of rocks of Tertiary age. The Tertiary rocks were deposited on an erosional surface that has considerable relief.

The Arikaree aquifer, as used in this report, consists predominantly of sandstone and conglomerate in the Arikaree Formation of early Miocene age and the Ogallala Formation of late Miocene and Pliocene age. In the western half of the area, sandy siltstone in the upper part of the White River Formation of 01igocene age is also considered as part of the aquifer. Although the Arikaree aquifer includes rocks in three formations, the rocks have similar hydraulic characteristics and appear to be in good hydraulic connection. Contours on the base of the Arikaree aquifer, as shown in figure 4, were drawn from interpretations of electric logs, drillers' logs, surface outcrops, and unpublished data by N. M. Denson. The Arikaree aquifer overlies relatively impermeable siltstone in the White River Formation in most of the area. Along the mountains in the western part of the area and along Guernsey Reservoir, the aquifer directly overlies rocks of pre-Tertiary age.

\section{Potentiometric Surface}

The configuration of the potentiometric surface in the Arikaree aquifer in September 1973 is shown in figure 5. The map is based on altitudes of measured water levels in the wells shown and altitudes along major streams. The altitude of land surface at each well was estimated either from topographic maps or surveys with an aneroid barometer. In general, the altitude of land surface was estimated from topographic maps to an accuracy of plus or minus $10 \mathrm{ft}(3 \mathrm{~m})$ and was estimated with an aneroid barometer to an accuracy of plus or minus $5 \mathrm{ft}(2 \mathrm{~m})$. Ground water moves through the Arikaree aquifer toward the major streams, and water in the aquifer is semi-confined under some stream valleys. Thus, the altitude of the potentiometric surface under some stream valleys is slightly higher than the altitude of the water table in flood-plain deposits and water in streams.

\section{Saturated Thickness}

The saturated thickness of the Arikaree aquifer in September 1973, as shown in figure 6, was approximated by subtracting the altitude of the base of the aquifer from the altitude of the potentiometric surface. The aquifer is over $700 \mathrm{ft}(210 \mathrm{~m})$ thick in the south-central part of the area; however, the saturated thickness is less than $300 \mathrm{ft}$ (91 $\mathrm{m}$ ) in over half of the area. 


\section{Hydraulic Conductivity}

Hydraulic conductivity is a parameter that describes the ability of an aquifer to transmit water (Lohman and others, 1972, p. 4). Hydraulic conductivities of the Arikaree aquifer that were determined from two aquifer tests in the study area and six tests in Wheatland Flats (Weeks, 1964, p. 40) ranged from 0.4 to $4 \mathrm{ft} /$ day $(0.1$ to $1 \mathrm{~m} /$ day). Using specific capacity data from 12 other wells in the study area and a series of curves by Meyer (1963), the hydraulic conductivity was estimated to range from 0.7 to $7 \mathrm{ft} /$ day $(0.2$ to $2 \mathrm{~m} / \mathrm{day})$.

\section{Specific Yield}

Specific yield is a parameter that describes the amount of water that will be released from an aquifer as the head in the aquifer is lowered by gravity drainage (Lohman and others, 1972, p. 12). For an unconfined aquifer, such as the Arikaree aquifer in the Dwyer area, the specific yield is approximately equal to the storage coefficient.

An average specific yield of 0.12 was computed by dividing the difference between the volume of water discharged from and recharged to the Arikaree aquifer by the change in saturated volume during January and February 1974. During this 2-month period, most of the discharge from the aquifer was leakage to flood-plain deposits along streams and evapotranspiration losses in the bluffs along the Wheatland fault system and Guernsey Reservoir. Very little water was being pumped. Discharge measurements along streams and estimates of evapotranspiration and underflow, as described in following sections of this report, indicate that discharge from the Arikaree aquifer was about $21.4 \mathrm{ft}^{3} / \mathrm{s}\left(0.606 \mathrm{~m}^{3} / \mathrm{s}\right)$ during this period. Estimated recharge from precipitation and the North Laramie Canal during this period averaged about $5.4 \mathrm{ft}^{3} / \mathrm{s}\left(0.15 \mathrm{~m}^{3} / \mathrm{s}\right)$. The difference between the volume discharged and recharged during the 2 -month period was about $8.1 \times 10^{7} \mathrm{ft}^{3}\left(2.3 \times 10^{6} \mathrm{~m}^{3}\right)$.

The change in volume of saturated material within the aquifer was calculated by using the Theissen mean method (Theissen, 1911, p. 1082). The method involves constructing a polygon around each well in which water levels were observed and assuming that the change in water level in the well is the change in water level throughout the area of the polygon. Changes in the volume of saturated material are computed by multiplying the changes in water level by the area of each polygon. Thirty-four observation wells were used in the determination. The volume of saturated material was decreased by about $6.9 \times 10^{8} \mathrm{ft}^{3}$ $\left(2.0 \times 10^{7} \mathrm{~m}^{3}\right)$ during the 2 -month period.

The specific yield of the Arikaree aquifer varies with depth because of differences in the water-bearing properties of the rock lying at different depths in the aquifer, but the value of 12 percent represents a fairly accurate average for the aquifer as a whole. The value of 12 percent also agrees with the estimated specific yield determined by Weeks (1964, p. 22-25) in Wheatland Flats using the same method. 


\section{Recharge from Precipitation}

Precipitation is the major source of recharge to the Arikaree aquifer in the study area, and it was estimated that 6.5 percent of the precipitation recharges the aquifer. The estimate was based on the following assumptions: 1) Prior to irrigation in the area, the 1ong-term rate of natural recharge to the aquifer was equal to the long-term rate of natural discharge; 2) natural discharge does not vary appreciably during the year; 3) the long-term rate of natural discharge was equal to the rate of natural discharge that occurred during water year 1974 in those parts of the study area not affected by recharge from the North Laramie Canal; and 4) precipitation throughout the Dwyer area is equal to the rate of precipitation measured by the U.S. Weather Bureau at Wheatland about $6 \mathrm{mi}(10 \mathrm{~km})$ south of the study area.

Stream discharge measurements made along Cottonwood Creek, the North Platte River, and lower reaches of the Laramie River during water year 1974 showed that natural discharge from the Arikaree aquifer averaged about $0.06\left(\mathrm{ft}^{3} / \mathrm{s}\right) / \mathrm{mi}^{2}\left[7 \times 10^{-4}\left(\mathrm{~m}^{3} / \mathrm{s}\right) / \mathrm{km}^{2}\right]$. Discharge from the aquifer is described in following sections of the report. Because precipitation is the only source of recharge to that part of the Arikaree aquifer that contributed water to these streams, the rate of discharge is assumed to be equal to the long-term rate of recharge from precipitation. Average annual precipitation at Wheatland is $1.04 \mathrm{ft}(0.317 \mathrm{~m})$, and 6.5 percent of the precipitation must recharge the aquifer to balance natural discharge. The figure of 6.5 percent compares favorably with an estimate of 5.5 percent made by Morgan (1946, p. 19) in a study of the Ogallala Formation near Cheyenne about $70 \mathrm{mi}(120 \mathrm{~km})$ south of the Dwyer area.

\section{Leakage Along Streams}

Leakage from the Arikaree aquifer through the flood-plain deposits to the major streams is the largest source of natural discharge from the aquifer in the Dwyer area. Discharge measurements along streams and estimates of flow through the flood-plain deposits indicate that leakage from the Arikaree aquifer along streams was about $19 \mathrm{ft}^{3} / \mathrm{s}\left(0.54 \mathrm{~m}^{3} / \mathrm{s}\right)$ during the winter of water year 1974. This rate of leakage is believed to be a fairly accurate estimate of the long-term rate of leakage prior to pumpage in the area because the potentiometric surface of the Arikaree aquifer and the water table in the flood-plain deposits have not changed appreciably since the study by Morris and Babcock (1960).

The location of gaging stations and other sites used for discharge measurements are shown in figure 3. Discharges at the sites are listed in table 1. 
Table 1.--Discharge measurements made at various sites along streams and the North Laramie Canal

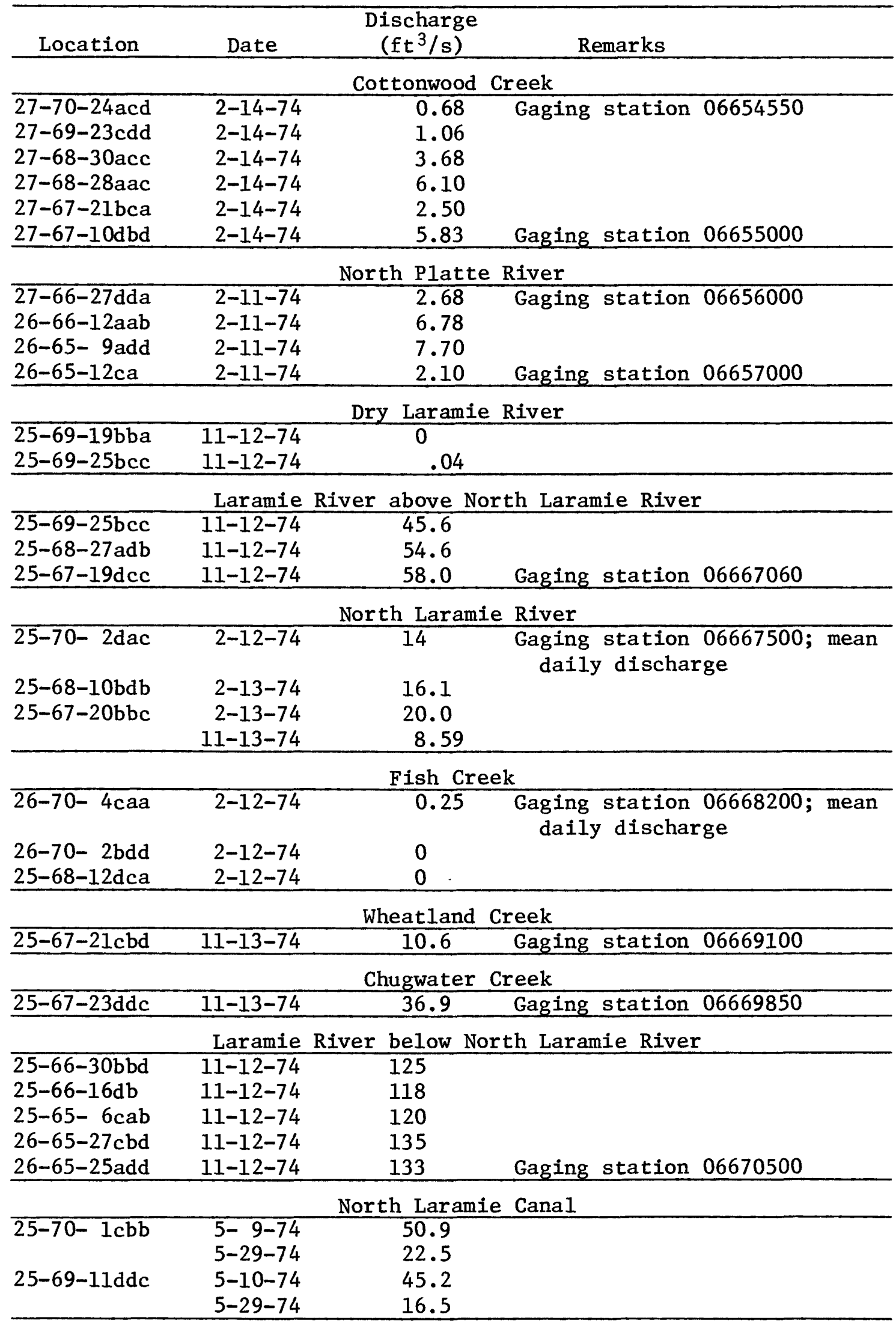


Gains or losses in streamflow between discharge measurement sites do not accurately represent leakage from the Arikaree aquifer because of changes in the ability of the flood-plain deposits to transmit and store water, and because of recharge to the flood-plain deposits from precipitation. Surface areas of the Arikaree aquifer and flood-plain deposits that contribute water to each stream (areas between ground-water divides) were determined with a planimeter. It was assumed that the flood-plain deposits and the Arikaree aquifer were recharged from precipitation at the same rate, and thus contribution to the total increase in flow through the flood-plain deposits and in the stream was proportional to their contributing surface areas. The discharge measurements used to determine leakage were made in the winter at times when there was no direct runoff and no irrigation diversions. Evapotranspiration losses along the streams were considered as negligible because plants were in a dormant state.

\section{Cottonwood Creek}

Leakage from the Arikaree aquifer along Cottonwood Creek was estimated to average about $5 \mathrm{ft}^{3} / \mathrm{s}\left(0.1 \mathrm{~m}^{3} / \mathrm{s}\right)$ during water year 1974 . Measurements on February 14, 1974 showed losses and gains in flow along individual reaches; however, the stream had a net gain in flow of $5.15 \mathrm{ft}^{3} / \mathrm{s}\left(0.146 \mathrm{~m}^{3} / \mathrm{s}\right)$. Flow through the flood-plain deposits into and out of the study reach was considered negligible because of the small thickness of the deposits along the extreme upper and lower reaches. Based on surface area, recharge to the flood-plain deposits from precipitation was estimated to contribute about 10 percent of the net gain in streamflow or about $0.5 \mathrm{ft}^{3} / \mathrm{s}\left(0.01 \mathrm{~m}^{3} / \mathrm{s}\right)$. The flow contribution along Cottonwood Creek from the Arikaree aquifer averaged about $0.06\left(\mathrm{ft}^{3} / \mathrm{s}\right) / \mathrm{mi}^{2}\left[7 \times 10^{-4}\left(\mathrm{~m}^{3} / \mathrm{s}\right) / \mathrm{km}^{2}\right]$.

\section{North Platte River}

Leakage along the North Platte River from that part of the Arikaree aquifer in the study area (south of river) was estimated to average about $3 \mathrm{ft}^{3} / \mathrm{s}\left(0.08 \mathrm{~m}^{3} / \mathrm{s}\right)$ during water year 1974. Measurements on February 11 , 1974 showed that the river had losses and gains in flow along individual reaches; however, the river had a net gain in flow of about $2 \mathrm{ft}^{3} / \mathrm{s}$ $\left(0.6 \mathrm{~m}^{3} / \mathrm{s}\right)$ throughout the study reach. The variability in streamflow is probably due to changes in the width, depth, and hydraulic conductivity of the flood-plain deposits. Flow into the study reach through the flood-plain deposits was considered negligible because of the small thickness of the deposits along the upper reach. Rapp and others (1957, p. 58) estimated that flow through the flood-plain deposits was about $5 \mathrm{ft}^{3} / \mathrm{s}\left(0.1 \mathrm{~m}^{3} / \mathrm{s}\right)$ near the lower end of the study reach. The total gain in flow through the flood-plain deposits and in the river was estimated to be about $7 \mathrm{ft}^{3} / \mathrm{s}\left(0.2 \mathrm{~m}^{3} / \mathrm{s}\right)$. Based on surface area, recharge to the flood-plain deposits from precipitation was estimated to 
contribute about 8 percent of the total gain in flow through the floodplain deposits and in the river, or about $0.6 \mathrm{ft}^{3} / \mathrm{s}\left(0.02 \mathrm{~m}^{3} / \mathrm{s}\right)$. As the gradient of the potentiometric surface of the Arikaree aquifer is approximately the same on both the north and south sides of the river, it was assumed that the rate of leakage from the aquifer was also the same on both sides. The flow contribution along the North Platte River from that part of the Arikaree aquifer in the study area averaged about $0.06\left(\mathrm{ft}^{3} / \mathrm{s}\right) / \mathrm{mi}^{2}\left[7 \times 10^{-4}\left(\mathrm{~m}^{3} / \mathrm{s}\right) / \mathrm{km}^{2}\right]$.

\section{North Laramie River}

Leakage from the Arikaree aquifer along the North Laramie River during water year 1974 was estimated to average about $6 \mathrm{ft}^{3} / \mathrm{s}\left(0.2 \mathrm{~m}^{3} / \mathrm{s}\right)$. Measurements on February 12 and 13,1974 showed that the river had a net gain in flow of $6.0 \mathrm{ft}^{3} / \mathrm{s}\left(0.17 \mathrm{~m}^{3} / \mathrm{s}\right)$ along the study reach. Flow into the study reach through the flood-plain deposits was considered insignificant because of the small thickness of the deposits along the upper reach. Using estimates of hydraulic conductivity of the floodplain deposits and sample logs by Morris and Babcock (1960, p. 69 and 174), flow through the deposits along the lower reach of the stream was estimated to be about $0.5 \mathrm{ft}^{3} / \mathrm{s}\left(0.01 \mathrm{~m}^{3} / \mathrm{s}\right)$. Based on surface area, recharge to the flood-plain deposits from precipitation was estimated to contribute about 7 percent of the total gain in flow through the floodplain deposits and in the river, or about $0.4 \mathrm{ft}^{3} / \mathrm{s}\left(0.01 \mathrm{~m}^{3} / \mathrm{s}\right)$. The flow contribution along the North Laramie River from the Arikaree aquifer averaged about $0.08\left(\mathrm{ft}^{3} / \mathrm{s}\right) / \mathrm{mi}^{2}\left[9 \times 10^{-4}\left(\mathrm{~m}^{3} / \mathrm{s}\right) / \mathrm{km}^{2}\right]$. The flow contribution of the Arikaree aquifer was higher than along Cottonwood Creek and the North Platte River because the aquifer in this area is also recharged by seepage from the North Laramie Canal, in addition to precipitation. Recharge from the canal is described in more detail in a following section of this report.

\section{Laramie River above North Laramie River}

Leakage from the Arikaree aquifer in the study area was estimated to average about $2 \mathrm{ft}^{3} / \mathrm{s}\left(0.06 \mathrm{~m}^{3} / \mathrm{s}\right)$ along the Laramie River between the Dry Laramie River and North Laramie River during water year 1974 . Gains or losses in flow could not be accurately determined along the Laramie River during the winter of water year 1974 because the flow was abnormally high, and gains and losses were a small percentage of the river discharge. Measurements on November 12, 1974 showed that the river had a net gain in flow of $12.4 \mathrm{ft}^{3} / \mathrm{s}\left(0.351 \mathrm{~m}^{3} / \mathrm{s}\right)$ along the study reach. There is probably no significant increase in flow through the floodplain deposits throughout the entire reach. Using estimates of hydraulic conductivity and sample logs by Morris and Babcock (1960, p. 69 and 177), flow through the flood-plain deposits was about $0.5 \mathrm{ft}^{3} / \mathrm{s}$ $\left(0.01 \mathrm{~m}^{3} / \mathrm{s}\right)$. Based on surface area, recharge to the flood-plain deposits 
from precipitation was estimated to contribute about 6 percent of the total gain in flow through the flood-plain deposits and in the river or about $0.7 \mathrm{ft}^{3} / \mathrm{s}\left(0.02 \mathrm{~m}^{3} / \mathrm{s}\right)$. As the gradient of the potentiometric surface on the south side of the river is about four times as steep as the gradient on the north side in the study area (Morris and Babcock, 1960, p1. 1), it was assumed that leakage from the Arikaree aquifer along the north side was 20 percent of the total rate of leakage. The flow contribution along the upper reaches of the Laramie River from the Arikaree aquifer in the study area averaged about $0.2\left(\mathrm{ft}^{3} / \mathrm{s}\right) / \mathrm{mi}^{2}$ $\left[2 \times 10^{-3}\left(\mathrm{~m}^{3} / \mathrm{s}\right) / \mathrm{km}^{2}\right]$. The flow contribution per square mile of aquifer was much higher than along any other stream in the study area because the aquifer in this area receives a large percentage of recharge from the North Laramie Canal.

\section{Laramie River below North Laramie River}

Leakage from the Arikaree aquifer in the study area was estimated to average about $3 \mathrm{ft}^{3} / \mathrm{s}\left(0.08 \mathrm{~m}^{3} / \mathrm{s}\right)$ along the Laramie River between the mouth of the North Laramie River and the Wheatland fault system during water year 1974. Measurements made along the river and along Wheatland and Chugwater Creeks on November 12 and 13, 1974 showed that the river had significant gains and losses in flow along individual reaches; however, the net gain in streamflow in the river throughout the study reach was about $5 \mathrm{ft}^{3} / \mathrm{s}\left(0.1 \mathrm{~m}^{3} / \mathrm{s}\right)$. Flow into the reach through $\mathrm{flood}-$ plain deposits along the North Laramie River and upper reaches of the Laramie River was estimated to be $1 \mathrm{ft}^{3} / \mathrm{s}\left(0.03 \mathrm{~m}^{3} / \mathrm{s}\right)$ as discussed in previous sections of the report. Flow into the reach through floodplain deposits along Wheatland and Chugwater Creeks was considered negligible. Rapp and others (1957, p. 58) estimated that flow through the flood-plain deposits along the Laramie River near the Platte and Goshen County line was about $3 \mathrm{ft}^{3} / \mathrm{s}\left(0.08 \mathrm{~m}^{3} / \mathrm{s}\right)$, and the figure is a fairly accurate estimate of flow through the deposits at the Wheatland fault system. Based on surface area, recharge to the flood-plain deposits from precipitation was estimated to contribute about 6 percent of the total gain in flow through the flood-plain deposits and in the river or about $0.4 \mathrm{ft}^{3} / \mathrm{s}(0.01 \mathrm{~m} / \mathrm{s})$. As the gradient of the potentiometric surface of the Arikaree aquifer is approximately the same on both sides of the river, it was assumed that the rate of leakage from the aquifer was also the same on both sides. The flow contribution along this reach of the Laramie River from that part of the Arikaree in the study area averaged about $0.06\left(\mathrm{ft}^{3} / \mathrm{s}\right) / \mathrm{mi}^{2}\left[7 \times 10^{-4}\left(\mathrm{~m}^{3} / \mathrm{s}\right) / \mathrm{km}^{2}\right]$.

\section{Evapotranspiration}

Evapotranspiration losses directly from the Arikaree aquifer were considered negligible in most of the area because there are few phreatophytes away from stream flood plains and the saturated zone is usually greater than $50 \mathrm{ft}(15 \mathrm{~m})$ below land surface. However, water that moves through the Arikaree aquifer towards the bluffs along the southwest 
side of Guernsey Reservoir and the Wheatland fault system is consumed by evapotranspiration. There are many juniper and pine trees along the bluffs in these two areas. Evapotranspiration losses from the aquifer in each of these areas were estimated to average $1 \mathrm{ft}^{3} / \mathrm{s}\left(0.03 \mathrm{~m}^{3} / \mathrm{s}\right)$. The estimate was based on the assumption that the system was in equilibrium in these two areas and that the amount of water discharged from the aquifer was equal to the amount recharged. Discharge measurements along the North Platte River and lower reaches of the Laramie River indicate that natural discharge from the aquifer averages about $0.06(\mathrm{ft} / \mathrm{s}) / \mathrm{mi}^{2}$ $\left[7 \times 10^{-4}\left(\mathrm{~m}^{3} / \mathrm{s}\right) / \mathrm{km}^{2}\right]$.

\section{Underflow}

Water that moves through the Arikaree aquifer towards the Dry Laramie River is discharged along the Laramie River upstream from the project area. Underflow out of the project area along the Dry Laramie River was estimated to average $0.4 \mathrm{ft} / \mathrm{s}\left(0.01 \mathrm{~m}^{3} / \mathrm{s}\right)$. Here again the estimate was based on the assumption that natural discharge (underflow) was equal to natural recharge and averaged $0.06\left(\mathrm{ft}^{3} / \mathrm{s}\right) / \mathrm{mi}^{2}$ $\left[7 \times 10^{-4}\left(\mathrm{~m}^{3} / \mathrm{s}\right) / \mathrm{km}^{2}\right]$. Measurements made on the Dry Laramie River on November 12, 1974 showed that the stream had a net gain in flow of $0.04 \mathrm{ft}^{3} / \mathrm{s}\left(0.001 \mathrm{~m}^{3} / \mathrm{s}\right)$. The gain in flow is probably due to water discharged from the flood-plain deposit along the stream.

Some water probably leaks from Precambrian granite into the Arikaree aquifer along the western boundary of the study area. However, because of the low permeability of the granite, the amount of water recharged to the aquifer from the granite is probably very small. It was considered negligible in this study.

\section{Recharge from North Laramie Canal}

The Arikaree aquifer between the North Laramie River and upper reaches of the Laramie River was recharged by seepage from the North Laramie Canal during water year 1974. Water is usually diverted into the canal from the North Laramie River during April through June, and water is stored in four reservoirs along the canal for use later in the irrigation season. Water in the reservoirs is also used for livestock watering and recreation. The total length of the canal is about $16 \mathrm{mi}$ $(26 \mathrm{~km})$; the first reservoir is about $8 \mathrm{mi}(13 \mathrm{~km})$ below the point of diversion from the river. Discharge measurements made during May 9 and 10, 1974 indicated that the water loss between the point of diversion and the first reservoir was $5.7 \mathrm{ft}^{3} / \mathrm{s}\left(0.16 \mathrm{~m}^{3} / \mathrm{s}\right)$. However, because of evapotranspiration 1osses, an accurate estimate of recharge could not be obtained directly from discharge measurements along the canal. 
Natural discharge from the aquifer during water year 1974 averaged about $0.06\left(\mathrm{ft}^{3} / \mathrm{s}\right) / \mathrm{mi}^{2}\left[7 \times 10^{-4}\left(\mathrm{~m}^{3} / \mathrm{s}\right) / \mathrm{km}^{2}\right]$ in areas not affected by recharge from the canal. However, discharge from the aquifer averaged $0.08\left(\mathrm{ft}^{3} / \mathrm{s}\right) / \mathrm{mi}^{2}\left[9 \times 10^{-4}\left(\mathrm{~m}^{3} / \mathrm{s}\right) / \mathrm{km}^{2}\right]$ along the North Laramie River and $0.2\left(\mathrm{ft}^{3} / \mathrm{s}\right) / \mathrm{mi}^{2}\left[2 \times 10^{-3}\left(\mathrm{~m}^{3} / \mathrm{s}\right) / \mathrm{km}^{2}\right]$ along the upper reaches of the Laramie River. It was assumed that without recharge from the canal the discharge from the aquifer along these two streams would also have averaged $0.06\left(\mathrm{ft}^{3} / \mathrm{s}\right) / \mathrm{mi}^{2}\left[7 \times 10^{-4}\left(\mathrm{~m}^{3} / \mathrm{s}\right) / \mathrm{km}^{2}\right]$. Thus, 25 percent of the water discharged from the Arikaree aquifer along the North Laramie River and 70 percent of the water discharged from the aquifer along the north side of the upper reaches of the Laramie River was originally recharged to the aquifer by seepage from the canal. Annual recharge from the canal is estimated to be about 2,100 acre-ft $\left(2.6 \mathrm{hm}^{3}\right)$.

\section{Pumpage}

Pumpage from the Arikaree aquifer by irrigation wells was estimated from efficiency test data collected by the Wyoming Department of Economic Planning and Development and from electrical power consumption. Annual power consumption for 1970 through 1973 was obtained for each well from records of the Wheatland Rural Electric Association. The power meter of each well was read once a month during the irrigation season of 1974 . An average of $1.4 \mathrm{ft}(0.43 \mathrm{~m})$ of water was applied, mostly by center-pivot sprinkler systems, for irrigation during 1974. Since the amount that was applied was generally less than estimated consumptive irrigation requirements of the most common crops (Trelease and others, 1970, p. 78), it was assumed that the amount of pumped irrigation water that returned to the aquifer was negligible. The number of irrigation we11s and the estimated quantity of water that was pumped from the Arikaree aquifer during water years 1969 through 1974 is shown in figure 2 .

\section{THE DIGITAL MODEL}

An aquifer system with complex boundary conditions, spatially varying aquifer properties, and time varying sources of recharge and discharge, such as the Arikaree aquifer in the Dwyer area, cannot be readily simulated by standard analytical methods. However, digital computer models are well suited for solution of such problems.

The aquifer model used in this study has evolved from Pinder's (1970) original model and modifications by Trescott (1973). Further minor modifications of the model, primarily in data input and the output, were made by the author for use in this study. 
In the model, the differential equation for two-dimensional nonsteady flow of a homogeneous compressible fluid in an elastic nonhomogeneous aquifer is approximated by a finite-difference equation as derived by Pinder and Bredehoeft (1968). Simulation of the aquifer system is accomplished by subdividing the study area into a large number of rectangular cells which constitute a finite-difference grid. Node points are located at the center of each cell. The finite-difference equation is solved for each node point in the grid by a digital computer using the iterative alternating direction implicit technique.

The major steps followed in the digital model are outlined in figure 7. The first step is to define the boundary conditions, hydraulic properties, and head in the aquifer at the start of the simulation. Then all hydrologic stresses imposed on the system during a specified period of time (pumping period) are defined. The accuracy of the numerical calculations is strongly affected by the length of the pumping period being simulated, and several time steps are usually used to complete the simulation of each pumping period. The initial time step is short, and the length of each successive time step is progressively increased until the total time of all steps equals the time of the pumping period. The head distribution in the aquifer and the leakage is calculated at the end of each time step, and they are printed at the end of each pumping period. This procedure is then repeated for each pumping period in the simulation.

\section{MODEL CALIBRATION}

The finite-difference grid and boundary conditions that were used to model the Arikaree aquifer are shown in figure 8 . The grid consists of 59 rows and 35 columns, and each cell is $0.50 \mathrm{mi}(0.80 \mathrm{~km})$ square. The model was calibrated on a month1y basis for water year 1974 using an IBM $370 / 155^{1}$ digital computer. Each pumping period (one month) was simulated with 14 time steps. The first time step was about 0.8 hour, and each successive time step was 1.5 times larger than the previous step.

1 The use of the brand name in this report is for identification purposes only and does not imply endorsement by the U.S. Geological Survey. 


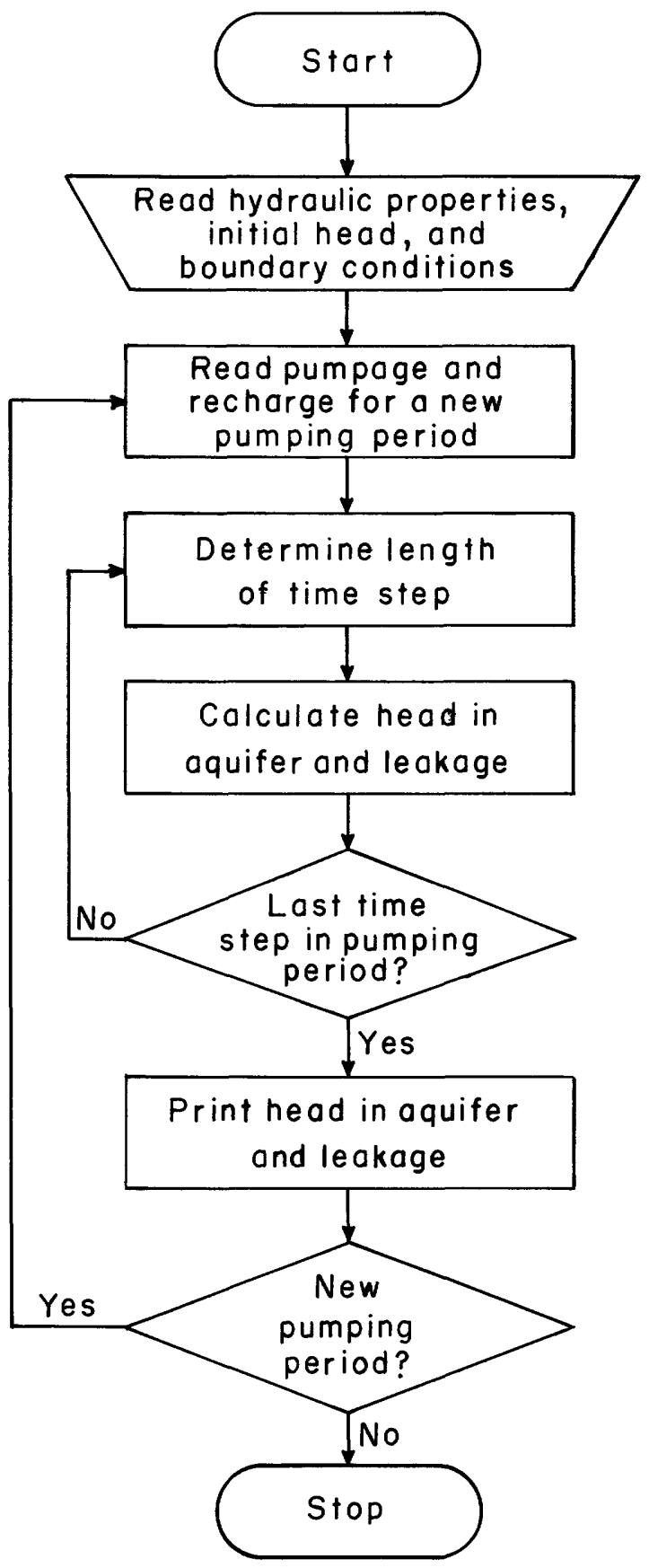

Figure 7.-Simplified flow chart showing major steps of the digital model. 
Model calibration consisted of matching calculated month1y changes in the potentiometric surface with observed changes in the 34 observation wells shown in figure 3. Calculated leakage from the aquifer to floodplain deposits was also matched with estimates of leakage made from field data. To obtain the best agreement between observed and calculated changes in the potentiometric surface and leakage, the hydraulic conductivity and the head in the aquifer at the beginning of water year 1974 were adjusted within the reliable limits of the field data. The hydraulic conductivity was varied from 0.5 to $4.3 \mathrm{ft} / \mathrm{day}(0.2$ to $1.3 \mathrm{~m} / \mathrm{day})$. The greatest change in hydraulic conductivity between adjacent nodes was by a factor of 2.5. Probably the largest source of error in the input data was in the monthly recharge from precipitation which was assumed to equal 6.5 percent of the monthly precipitation and to occur at the same rate throughout the area.

The greatest observed rise in the potentiometric surface in the 34 observation wel1s that were measured during water year 1974 was $2.81 \mathrm{ft}$ $(0.856 \mathrm{~m})$, and the greatest decline was $6.83 \mathrm{ft}(2.08 \mathrm{~m})$. The calculated head in the aquifer was within $1 \mathrm{ft}(0.3 \mathrm{~m})$ of the observed head about 80 percent of the time. In general, the best agreement between observed and calculated changes in head were in areas of greatest pumpage and was worst in areas of no pumpage. Figure 9 shows the observed and calculated heads in the aquifer at two wells. Well 26-68-36cbc is near an area of pumping, and well $25-66-18 \mathrm{bcc}$ is several miles from any significant ground-water withdrawal.

Calculated leakage from the Arikaree aquifer to the flood-plain deposits during water year 1974 is shown in figure 10. The rate of leakage is a function of the head difference between the potentiometric surface of the Arikaree aquifer and the water table in the flood-plain deposits across a confining layer. To accurately simulate leakage with the model, the confining layer was assigned a hydraulic conductivity of $8.6 \times 10^{-4} \mathrm{ft} /$ day $\left(2.6 \times 10^{-4} \mathrm{~m} / \mathrm{day}\right)$ and a thickness of $1 \mathrm{ft}(0.3 \mathrm{~m})$. In calculating leakage, heads in the Arikaree aquifer were allowed to change, but it was assumed that the water table in the flood-plain deposits did not change. In general, agreement was good between calculated leakage and estimates of leakage made from field data; differences were well within the reliable limits of the data. Estimated leakage to flood-plain deposits along streams and the range of calculated leakage during water year 1974 were as follows: Cottonwood. Creek, estimated $5 \mathrm{ft} 3 / \mathrm{s}(0.1 \mathrm{~m} 3 / \mathrm{s})$, calculated 4.73 to $5.05 \mathrm{ft} 3 / \mathrm{s}(0.134$ to $0.143 \mathrm{~m} 3 / \mathrm{s})$; North P1atte River, estimated $3 \mathrm{ft} 3 / \mathrm{s}(0.08 \mathrm{~m} 3 / \mathrm{s})$, calculated 2.53 to $2.72 \mathrm{ft} 3 / \mathrm{s}(0.0716$ to $0.0770 \mathrm{~m} 3 / \mathrm{s})$; North Laramie River, estimated $6 \mathrm{ft} 3 / \mathrm{s}\left(0.2 \mathrm{~m}^{3} / \mathrm{s}\right)$, calculated 5.74 to $6.33 \mathrm{ft} 3 / \mathrm{s}(0.163$ to $0.179 \mathrm{~m} 3 / \mathrm{s})$; Laramie River above North Laramie River, estimated $2 \mathrm{ft} 3 / \mathrm{s}(0.06 \mathrm{~m} 3 / \mathrm{s})$, calculated 2.31 to $2.35 \mathrm{ft} 3 / \mathrm{s}(0.0654$ to $0.0666 \mathrm{~m} 3 / \mathrm{s})$; and Laramie River below North Laramie River, estimated $3 \mathrm{ft} 3 / \mathrm{s}(0.08 \mathrm{~m} 3 / \mathrm{s})$, calculated 3.04 to $3.14 \mathrm{ft} 3 / \mathrm{s}(0.0861$ to $0.0889 \mathrm{~m} 3 / \mathrm{s})$. Total leakage was estimated to have averaged $19 \mathrm{ft}^{3} / \mathrm{s}\left(0.54 \mathrm{~m}^{3} / \mathrm{s}\right)$ during water year 1974 , and the calculated total ranged from 18.7 to $19.5 \mathrm{ft}^{3} / \mathrm{s}\left(0.530\right.$ to $\left.0.552 \mathrm{~m}^{3} / \mathrm{s}\right)$. 


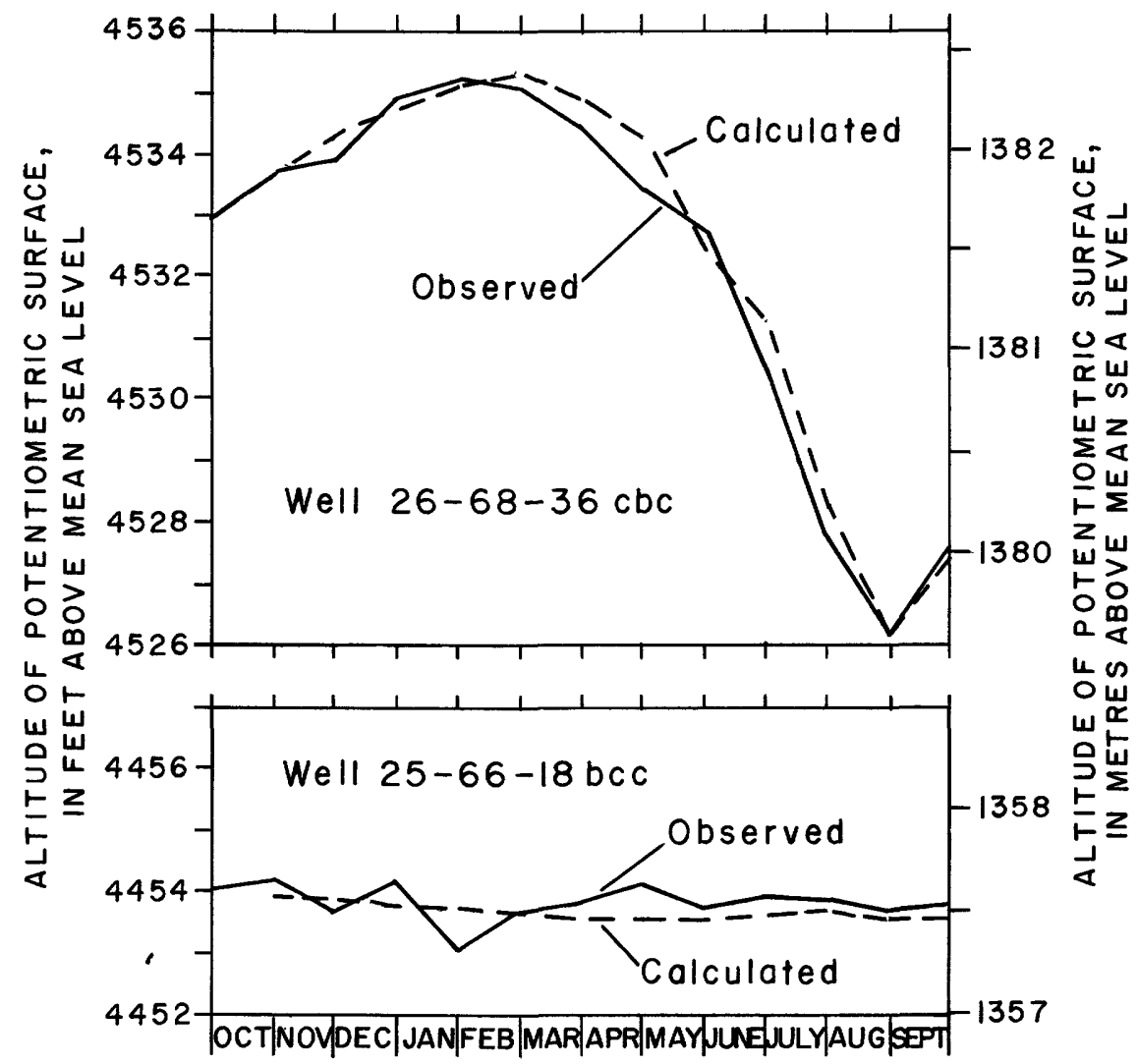

WATER YEAR 1974

Figure 9.-Observed and calculated potentiometric surface at two wells during calibration period. 


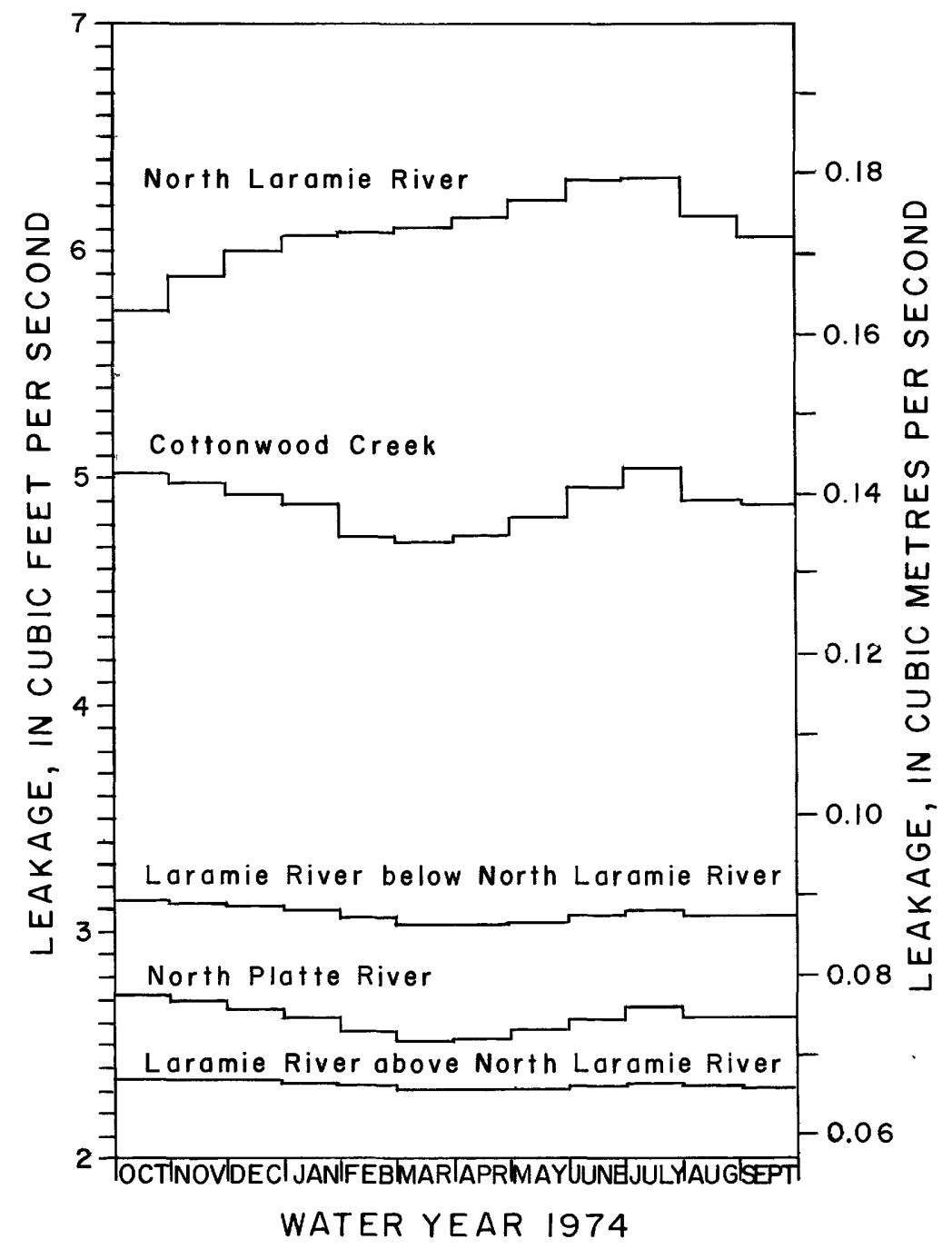

Figure 10.-Calculated leakage from the Arikaree aquifer to flood-plain deposits along streams in the Dwyer area during water year 1974. 
A11 sources of recharge and discharge that were used to calibrate the model for water year 1974 are shown in figure 11. "Constant discharge across boundary", as shown in figure 11, includes evapotranspiration losses and underflow and was simulated in the model by discharge wells. Because the mathematical boundary of the model did not exactly coincide with the actual boundary of the aquifer, some recharge wells were used along the boundary. Discharge and recharge wells along the boundary of the model assured that the potentiometric surface was maintained at an appropriate gradient near the boundary. The locations of recharge wells are shown in figure 8, and their total rate of recharga is shown as "constant recharge across boundary" in figure 11. Precipitation at Wheatland during water year 1974 was $0.702 \mathrm{ft}(0.214 \mathrm{~m})$ or about 68 percent of the long-term average. As a result of the low precipitation and pumpage, discharge from the aquifer exceeded recharge during most months. During the water year, discharge from the aquifer exceeded recharge by about 7,000 acre-ft $\left(9 \mathrm{hm}^{3}\right)$.

The transmissivity (saturated thickness times hydraulic conductivity) of the Arikaree aquifer in September 1973 is shown in figure 12. The transmissivity was generated by the model using saturated thickness and adjusted hydraulic conductivity that were used to calibrate the model. In general, the transmissivity of the aquifer is greatest in areas now (1975) developed.

\section{MODEL PREDICTIONS}

The calibrated model was used to predict the effects of 1974 pumping rates on the potentiometric surface of the Arikaree aquifer and leakage from the aquifer through water year 1979. Water years 1974-79 were each divided into two 6-month pumping periods. In turn, each pumping period was simulated by 15 time steps. The first time step was about 5 hours, and each successive time step was 1.5 times longer than the previous step.

In simulating water year 1974, monthly rates of pumpage, recharge from precipitation, and recharge from the North Laramie Canal that were used to calibrate the model on a monthly basis were averaged over the appropriate 6-month period. In simulating water years 1975-79, 1974 pumpage rates and recharge rates from the canal were used; however, 6.5 percent of the long-term rate of precipitation was used as the rate of recharge from precipitation.

The predicted change in the potentiometric surface of the Arikaree aquifer is shown in figure 13. The greatest predicted declines are in areas of greatest pumpage, and the largest predicted decline is $14 \mathrm{ft}$ $(4.3 \mathrm{~m})$. A slight rise in the potentiometric surface is predicted over much of the area. 


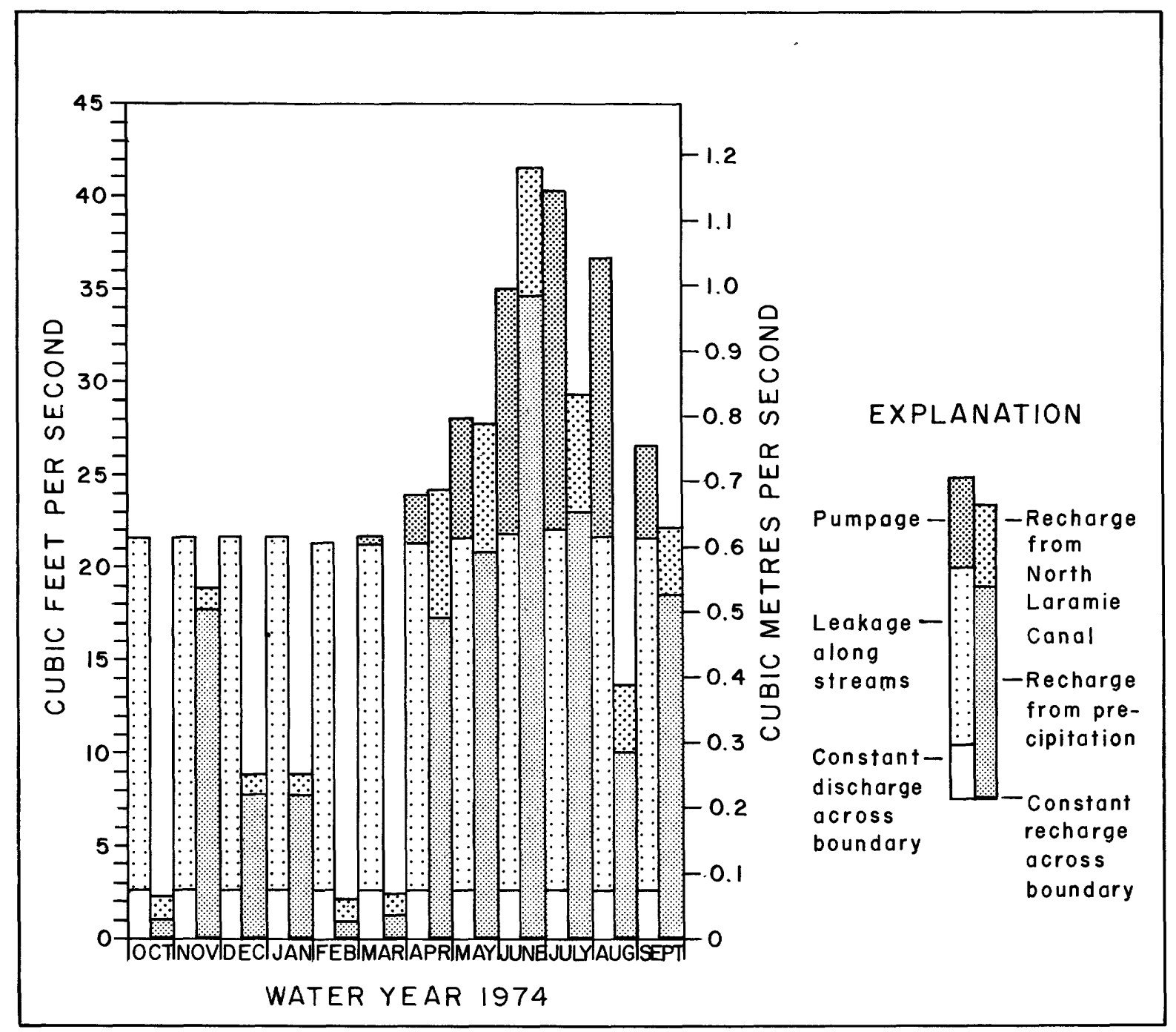

Figure 11.- Monthly recharge to and discharge from the Arikaree aquifer in the modeled area during water year 1974. 
Predicted leakage from the aquifer along streams during water years 1974-79 is shown in figure 14. The greatest change in leakage is predicted along the North Laramie River. A small decrease in leakage is predicted along Cottonwood Creek and along the upper reaches of the Laramie River. In general, leakage from the aquifer is predicted to decrease along those streams that are nearest to the areas of greatest pumpage. The total predicted decrease in leakage between water years 1974 and 1979 is about 500 acre-ft $\left(0.6 \mathrm{hm}^{3}\right)$ a year.

\section{SUMMARY AND CONCLUSIONS}

Observed changes in the potentiometric surface during water year 1974 were simulated by the model fairly well. Agreement between observed and calculated leakage from the aquifer along streams was within reliable limits of the field data.

The calibrated model was used to estimate changes in the potentiometric surface and leakage from the aquifer along streams through water year 1979. The largest declines in the potentiometric surface and leakage were predicted to occur near areas of the greatest pumpage; and much of the area would be relatively unaffected.

To further refine the model, more data are needed. Water levels should be measured in at least 10 wells on a semiannual basis (at the beginning and end of the irrigation season, April and October). Power consumption data should be collected at each well, and efficiency tests should be run on new wells. The specific yield of the aquifer should be determined at selected sites with aquifer tests of long enough duration to obtain reliable data. Estimates of recharge to the aquifer could probably be refined with recording rain gages at selected sites. Discharge measurements along streams should be made in the winter to monitor leakage from the aquifer. When significant new data become available, the model should be updated and recalibrated for the period covered by the data. 


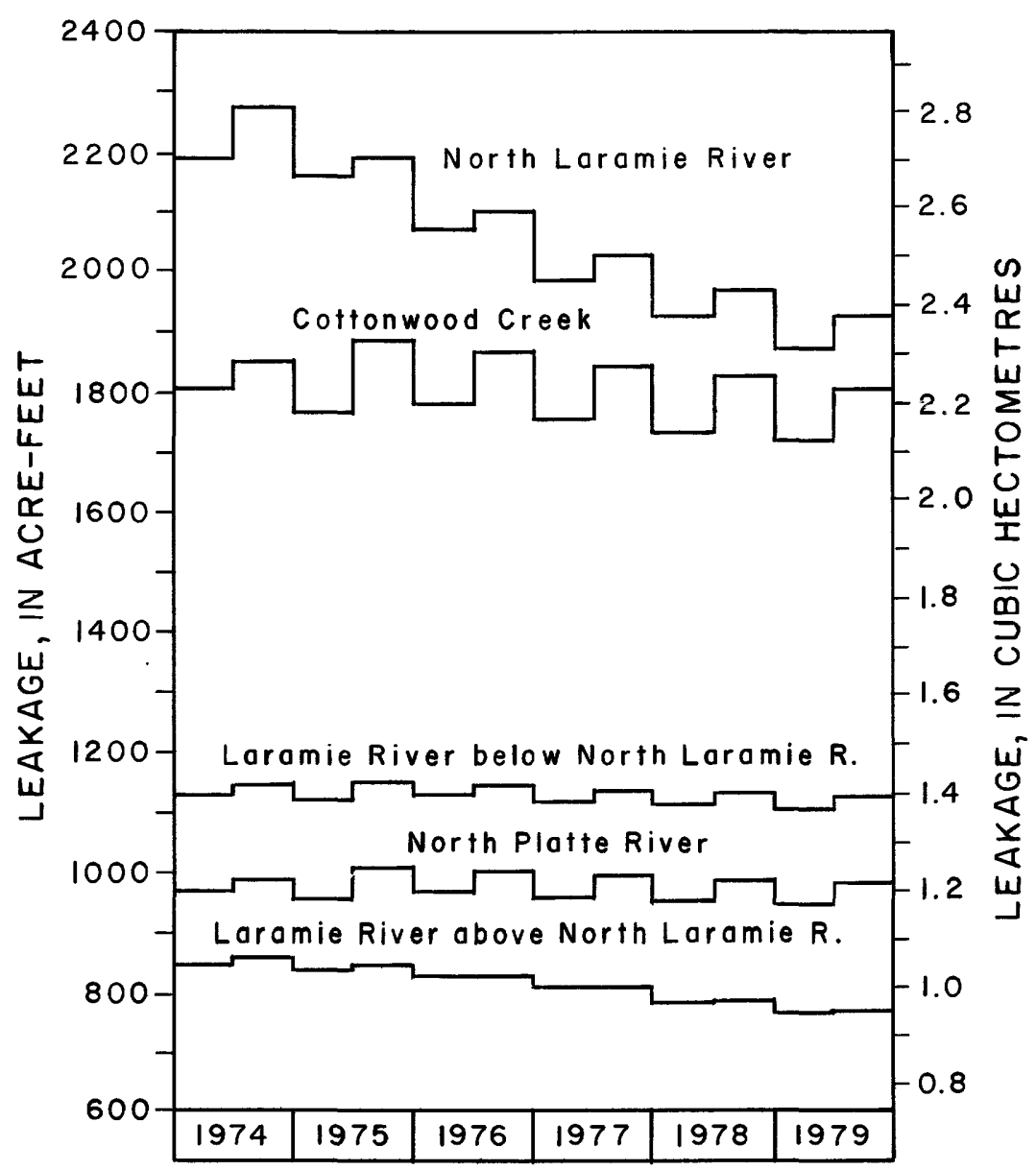

Figure 14.-Predicted leakage from the Arikaree aquifer along streams in the Dwyer area during water years 1974-79 assuming no new development after water year 1974 . 


\section{SELECTED REFERENCES}

Lohman, S. W., and others, 1972, Definitions of selected ground-water terms - revisions and conceptual refinements: U.S. Geo1. Survey Water-Supply Paper 1988, 21 p.

Meyer, R. R., 1963, A chart relating well diameter, specific capacity, and the coefficients of transmissibility and storage, in Methods of determining permeability, transmissibility and drawdown, compiled by Ray Benta11: U.S. Geol. Survey Water-Supply Paper 1536-I, p. 338-340.

Morgan, A. M., 1946, Progress report on geology and ground-water resources of the Cheyenne area, Wyoming: U.S. Geol. Survey open-file rept., 55 p.

Morris, D. A., and Babcock, H. M., 1960, Geology and ground-water resources of Platte County, Wyoming, with a section on Chemical quality of the water, by R. H. Langford: U.S. Geol. Survey Water-Supply Paper 1490, $195 \mathrm{p}$.

Pinder, G. F., 1970, A digital model for aquifer evaluation: U.S. Geol. Survey Techniques Water-Resources Inv., Book 7, Chap. C1, 18 p.

Pinder, G. F., and Bredehoeft, J. D., 1968, Application of the digital computer for aquifer evaluation: Water Resources Research, v. 4, no. 5, p. 1069-1093.

Rapp, J. R., and Babcock, H. M., 1953, Reconnaissance of the geology and ground-water resources of the Glendo-Wendover area, Platte County, Wyoming, with a section on the Chemical quality of the water, by W. H. Durum: U.S. Geol. Survey Circ. 163, 34 p.

Rapp, J. R., Visher, F. N., and Littleton, R. T., 1957, Geology and ground-water resources of Goshen County, Wyoming, with a section on Chemical quality of the ground water, by W. H. Durum: U.S. Geol. Survey Water-Supp1y Paper 1377, 145 p.

Theissen, A. H., 1911, Precipitation averages for large areas: Monthly Weather Rev., July, p. 1082.

Trelease, F. J., Swartz, T. J., Rechard, P. A., and Burman, R. D., 1970, Consumptive use of irrigation water in Wyoming: Wyoming Water Planning Rept. 5, Wyoming State Engineer's office, 83 p.

Trescott, P. C., 1973, Iterative digital model for aquifer evaluation: U.S. Geo1. Survey open-file rept., 63 p.

Weeks, E. P., 1964, Hydrologic conditions in the Wheatland Flats area, Platte County, Wyoming: U.S. Geo1. Survey Water-Supply Paper 1783, 79 p. 




$$
\text { - }
$$

